\title{
Stem anatomical study of some Iranian Marrubium L. species
}

\author{
SEYED MEHDI TALEBI ${ }^{1, \bullet}$, MASOUD SHEIDAI $^{2}$, FATEMEH ARIYANEJAD $^{1}$, ALEX MATSYURA $^{3}$ \\ ${ }^{1}$ Department of Biology, Faculty of Sciences, Arak University, Arak, 38156-8-8349 Iran. Tel.: +98-863-4173317. `email: seyedmehdi_talebi@yahoo.com. \\ ${ }^{2}$ Faculty of Life Sciences \& Biotechnology, Shahid Beheshti University, Tehran, Iran. \\ ${ }^{3}$ Altai State University. 656049 Barnaul, Altai Krai, Russian
}

Manuscript received: 18 July 2019. Revision accepted: 21 August 2019.

\begin{abstract}
Talebi SM, Sheidai M, Ariyanejad F, Matsyura A. 2019. Stem anatomical study of some Iranian Marrubium L. species. Biodiversitas 20: 2589-2595. Marrubium is one of problematic genera of Lamiaceae family which distributed in different parts of Iran with 11 species. These species have been used in folk medicine for treatment of different disorders. In the present study, we used stem anatomical characteristics of six Marrubium species for taxonomical treatment of the genus and delimitation of these species. Based on the geographical distribution, one to three populations were selected from each species. Stem hand transverses were double-stained and studied using Light Microscopy. In total, sixteen qualitative and quantitative anatomical traits were studied. Anatomical data were analyzed using MVSP and SPSS software. Stems in transverse section were quadrangle, with a continuous ring of vascular tissue. The anatomical characteristics varied among the species, while the ANOVA test revealed significant variations for some of them. The studied species and their populations were divided into two groups in the UPGMA dendrogram of anatomical data. Populations of each species did not cluster together and were scattered in these groups, except those for M. cuneatum, which were clustered in only one group. Furthermore, these groups were clearly observed in PCA plot. According to CA-joined plot, each group or population had distinct anatomical feature (s) which was useful in identification of them. In some cases, the clustering pattern agreed with previous molecular and morphological studies, while in several times populations clustering did not agree with traditional classification of species as Flora of Iran and Flora Iranica. It seems that some infraspecific ranks must be redefined.
\end{abstract}

Keywords: Marrubium, stem, anatomy, population, infraspecific variations

\section{INTRODUCTION}

The genus Marrubium L. (Lamiaceae-Lamioideae) is comprised of about 49 species (Ahvazi et al. 2016). The genus includes annual and perennial herbs. Although its taxa are mainly distributed in the Irano-Turanian as well as Mediterranean phytogeographic regions, some species are naturalized in America and Australia (Akgül et al. 2008). Some species of the genus like M. vulgare and M. anisodon are being used since ancient as a medicinal plant in the treatment of inflammation, edema, ear pain, appetizer, dyspepsia, high blood pressure, cardiac pains, spasm, flatulence, dyspepsia, and women infertility (Naghibi et al. 2005).

According to Flora Iranica (Rechinger 1982) and Flora of Iran (Jamzad 2012), Marrubium consists of 11 species in Iran, from them only one is endemic (M. procerum Bunge). Most Marrubium species are distributed in steppes, arid and semiarid areas of Iran (Halvorson 2003; Grassia et al. 2006). There are many discussions about infrageneric classification of the genus. Bentham (1834) revised this genus and divided Marrubium into two sections, namely Lagopsis and Marrubium. Boissier (1879) and Briquet (1896) divided the genus into two and three sections, respectively. However, in some countries such as Iran and Turkey, the Marrubium species were not classified into sections (Cullen 1982; Rechinger 1982; Jamzad 2012).

Radford et al. (1974) have suggested that anatomical characteristics have been used in taxonomical investigations for more than hundred years. Solereder (1908) summarized a lot of data about anatomical traits of some dicotyledonous families such as Crassulaceae, Dipterocarpaceae, and Myrsinaceae. Moreover, Metcalfe and Chalk (1950) gave a synthesis of previous works and their own investigations of several families.

Almeida et al. (2009) have suggested the phylogenetic use of anatomical characteristics in the delimitation of different genera. Furthermore, anatomical traits have been studied in descriptive works (Braga 1977; Benzing 2000), using an ecophysiological approach (Scarano et al. 2002), or used as a tool for taxonomic delimitations of the subgenera (Aoyama and Sajo 2003) and also for species of the genus (Proença and Sajo 2004). In addition, stem anatomical variables have great of taxonomical importance. For example, Terrazas and Arias (2003) produced a complete review about the stem anatomy and they emphasized the great relevance of anatomical features for taxonomy and evolution study.

There are few works on the anatomical study of Marrubium species, and most of them are descriptive study of some species such as M. vulgare (Moreno-Jimenez et al. 2006) and M. anisodon C. Koch (Talebi et al. 2019). The current investigation, describes the stem anatomical structure of six Marrubium species (including fourteen populations) with the aim of providing additional variables to support the taxonomic boundaries of the species, and also improvement of infrageneric classification of the genus. 


\section{MATERIALS AND METHODS}

\section{Plant materials}

We studied stem anatomical characteristics of fourteen populations of six Marrubium species from Iran (Table 1, Figure 1). Based on the distribution range, one to three populations of each species were investigated. Samples were identified according to the descriptions provided in different sources such as Flora of Iran (Jamzad 2012) and Flora Iranica (Rechinger 1982). A voucher sample for each studied plant was deposited in the Herbarium of Arak University (AUH).

\section{Preparation method}

Samples from the middle region of adult stems were fixed in the solution of FAA (Formaldehyde Acetic acid Alcohol) $50 \%$ for $48 \mathrm{~h}$ and then transferred and stored in 50\% alcohol (Johansen 1940). Transverse hand sections were obtained using a razor blade, bleached with sodium hypochlorite and stained with Carmine and Green Methyl (Bukatsch 1972). The thin slides were mounted in 50\% glycerin and observed with an Olympus $\mathrm{CH} 2$ Light Microscope (40X and 100X). We observed three samples of each population.

In total, sixteen qualitative and quantitative anatomical variables were evaluated. According to Metcalfe and Chalk (1950), the studied characteristics were: epidermal cell shape, length, width and length/width ratio, parenchyma cell length, width and length/width ratio, phloem tissue width, xylem cell diameter, pith cell length, width and length/width ratio, cortical collenchyma cell length, width and length/width ratio and epidermal cell layer number.

\section{Statistical analysis}

Quantitative anatomical variables were subjected to one-way analysis of variance (ANOVA) test to determine if significant variations existed among the species and their populations for each trait measured. Mean and standard deviations of features were calculated. The mentioned analyses were performed using SPSS ver. 15. Cluster analysis was carried out based on all of the studied characteristics using Unweighted Paired Group Method with Arithmetic Mean (UPGMA), Principal Coordinate Ordination (PCO (, Principal Coordinate Analysis (PCA) and Correspondence Analysis (C.A-Joined (in Multivariate Statistical Package ver. 2 (MVSP) software (Podani 2000).

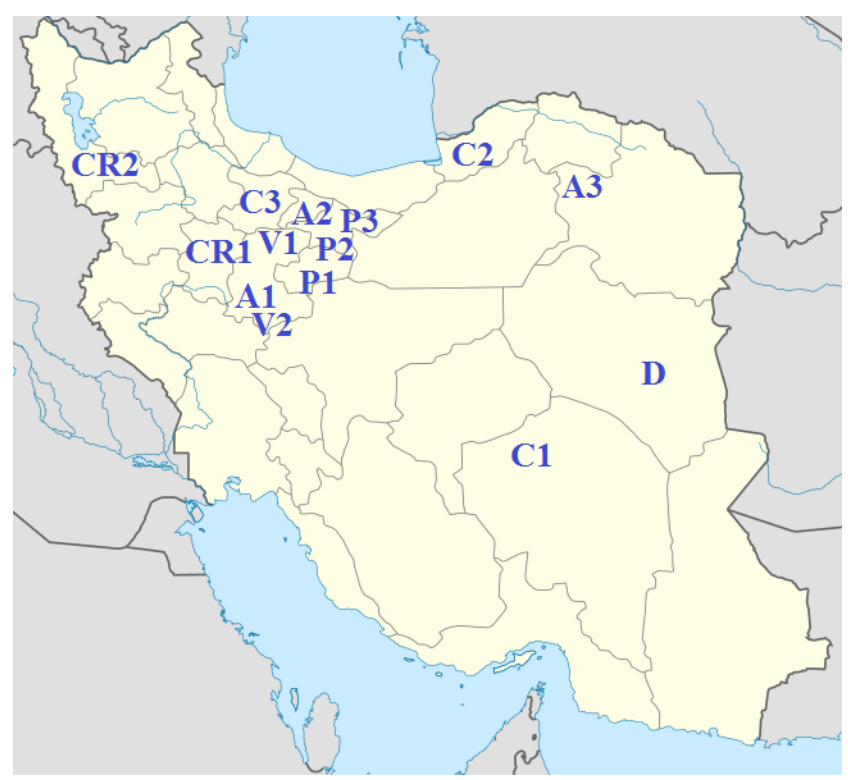

Figure 1. Distribution map of the studied species and their populations in Iran

Table 1. Localities address of the studied species and their populations

\begin{tabular}{|c|c|c|c|}
\hline Code & Species & Localities & Voucher number \\
\hline $\mathrm{A} 1$ & M. anisodon C. Koch. & Markazi province, Arak, Sefidkhani mountain, $1950 \mathrm{~m}$. & AUH8701 \\
\hline A2 & M. anisodon C. Koch. & Mazandaran province, Lasem, Polor, $2500 \mathrm{~m}$. & AUH8702 \\
\hline A3 & M. anisodon C. Koch. & Khorasan Razavi province, Nyshabur, $1400 \mathrm{~m}$. & AUH8703 \\
\hline $\mathrm{C} 1$ & M. cuneatum Russel. & Kerman province, Rabor, $1000 \mathrm{~m}$. & AUH8704 \\
\hline $\mathrm{C} 2$ & M. cuneatum Russel. & Golestan province, Gorgan, $500 \mathrm{~m}$. & AUH8705 \\
\hline $\mathrm{C} 3$ & M. cuneatum Russel. & Qazvin Province, Qazvin, 2100m. & AUH8706 \\
\hline CR1 & M. crassidens Boiss. & Hamadan, Hamekasi, 2100m. & AUH8707 \\
\hline $\mathrm{CR} 2$ & M. crassidens Boiss. & West Azerbaijan, $60 \mathrm{~km}$ Salmas to Urmia, $1700 \mathrm{~m}$. & AUH8708 \\
\hline $\mathrm{D}$ & M. duabense Murata & South Khorasan, Birjand, 1430m. & AUH8709 \\
\hline P1 & M. parviflorum Fisch. \& Mey. & Qom province, Salafchegan, Velashjerd, $1850 \mathrm{~m}$. & AUH87010 \\
\hline $\mathrm{P} 2$ & M. parviflorum Fisch. \& Mey. & Qom province, Salafchegan, Zavareh, 1400m. & AUH87011 \\
\hline P3 & M. parviflorum Fisch. \& Mey. & Tehran province, Lavasan, Fasham, 2000m. & AUH87012 \\
\hline V1 & M. vulgare $\mathrm{L}$. & Qom province, Salafchegan, Imamzadeh, $1850 \mathrm{~m}$. & AUH87013 \\
\hline $\mathrm{V} 2$ & M. vulgare $\mathrm{L}$. & Markazi province, Khomein, Varcheh, 1900m. & AUH87014 \\
\hline
\end{tabular}




\section{RESULTS AND DISCUSSION}

\section{Results}

In all of studied species and their populations, the stem in the transverse section was quadrangle. There was a continuous ring of 2-3-layered epidermis tissue in the stem. At the angle of stem, collenchyma cells were below the epidermis, the layer number of these cells varied among the populations. Cortex was composed of parenchyma cells, which had different shape and size. Xylem tissue formed a continuous cylinder around the pith cells and it is traversed by narrow rays. Phloem tissue made a continuous narrow ring around the xylem. The pith was composed of differentsized parenchyma cells.

The studied anatomical characteristics of the studied species and their populations were presented in Table 2. Both qualitative and quantitative anatomical characteristics varied among the studied populations.

The epidermis cell shape varied among the studied populations. In most of them, it was elliptic, while in some populations was circular such as populations CR1, CR2, P1, P2. Moreover, the shape of cortical parenchyma cells was observed as polygonal or circular. The numbers of both types were nearly equal.

The largest $(0.3 \mu \mathrm{m})$ and smallest $(0.14 \mu \mathrm{m})$ epidermis cells were reported from populations A1 and P1, respectively. In addition, the widest $(0.17 \mu \mathrm{m})$ and narrowest $(0.10 \mu \mathrm{m})$ epidermis cells existed in populations $\mathrm{A} 3$, and $\mathrm{C} 1$ and $\mathrm{C} 2$, respectively. Population A3 had the largest collenchyma cells, while population A1 had the smallest one. We found largest cortical parenchyma cells in populations $\mathrm{P} 3$ and A2, but both populations of CR had the smallest cortical cells. We had broadest phloem tissue in populations A1 and V1; however, populations D and CR1 had narrowest phloem tissue. Widest xylem tissue was registered in populations $\mathrm{C} 2, \mathrm{C} 3$, and $\mathrm{P} 1$, while narrowest xylem tissue was observed in populations CR2 and V2.

ANOVA test revealed significant difference $(\mathrm{P}<0.05)$ for some of the studied quantitative anatomical feature such as: epidermal layer number, collenchyma cell length, collenchyma cell width, collenchyma cell length/width ratio, and phloem tissue width (Table 3 ).

The studied species and their populations clustered separately in the UPGMA tree of anatomical characteristics (Figure 2). Moreover, PCA and PCO plots (Figures 3, 4) produced similar results; therefore species arrangement in the tree was discussed here. This tree had two clades; each of them was composed of seven populations. In clade A, two branches existed; branch $\mathrm{C}$ had two groups. Populations V1 and P2 were in the large group and the small group had population CR1. Moreover, branch D was divided into two groups. Population D, was in the small group, while the large group has composed of two subgroups. One sub-group has been composed of two populations $\mathrm{P} 1$ and $\mathrm{CR} 2$, but another sub-group had population A2. Clade B had two branches; branch E was composed of population $\mathrm{C} 1$, however, branch $\mathrm{F}$ was large and was composed of two groups. Each group was threemembered. Group $G$ was divided into two sub-groups, population $\mathrm{C} 3$ placed in a sub-group and populations P3 and A3 were clustered closely in a sub-group. This condition holds true for group $\mathrm{H}$ and we had two subgroups in it. Populations A1 and V2 were clustered as a sub-group, in addition, population of $\mathrm{C} 2$ existed in the other sub-group.

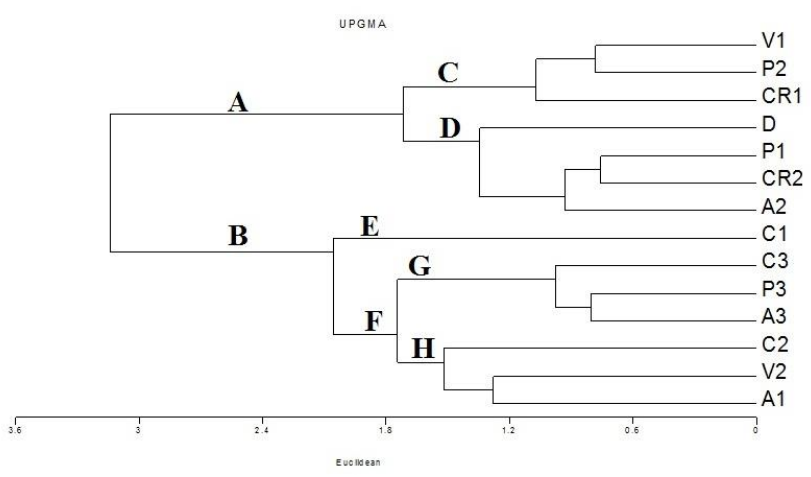

Figure 2. UPGMA dendrogram of six species and their populations according to the anatomical characteristics

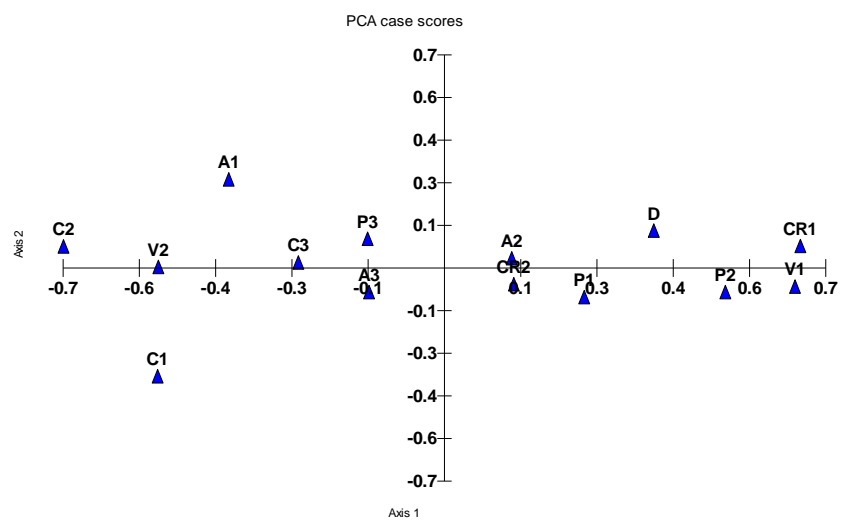

Figure 3. PCA plot of six species and populations based on the anatomical variables

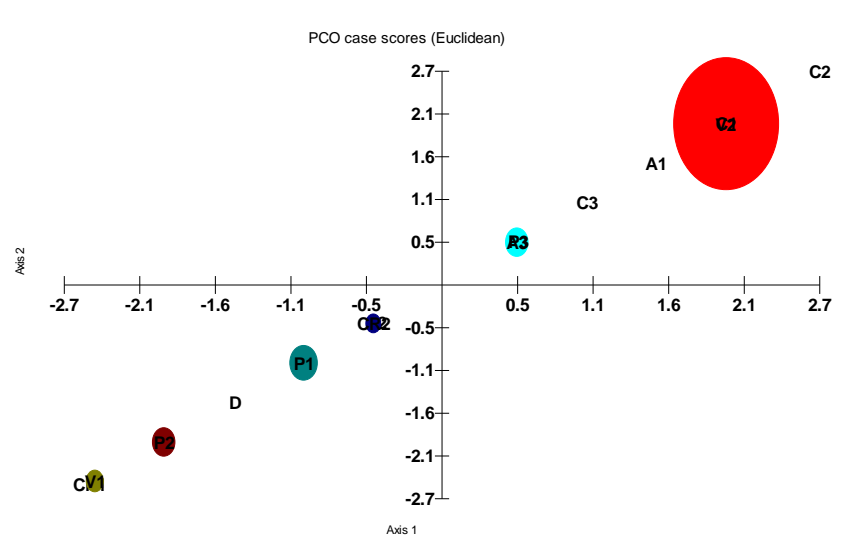

Figure 4. PCO plot of six species and their populations 
Table 2. Selected anatomical characteristics of the studied species and their populations (all values are in $\mu \mathrm{m}$ )

\begin{tabular}{|c|c|c|c|c|c|c|c|c|c|c|c|c|c|}
\hline Taxa & $\begin{array}{l}\text { Epidermis } \\
\text { cell length }\end{array}$ & $\begin{array}{l}\text { Epidermis } \\
\text { cell width }\end{array}$ & $\begin{array}{c}\text { Epidermal } \\
\text { layer } \\
\text { number }\end{array}$ & $\begin{array}{l}\text { Epidermis } \\
\text { cell shape }\end{array}$ & $\begin{array}{l}\text { Collenchyma } \\
\text { cell length }\end{array}$ & $\begin{array}{l}\text { Collenchyma } \\
\text { cell width }\end{array}$ & $\begin{array}{l}\text { Parenchyma } \\
\text { cell length }\end{array}$ & $\begin{array}{l}\text { Parenchyma } \\
\text { cell width }\end{array}$ & $\begin{array}{c}\text { Parenchyma } \\
\text { cell shape }\end{array}$ & $\begin{array}{c}\text { Phloem } \\
\text { tissue } \\
\text { length }\end{array}$ & $\begin{array}{l}\text { Phloem } \\
\text { tissue width }\end{array}$ & $\begin{array}{l}\text { Xylem } \\
\text { tissue } \\
\text { length } \\
\end{array}$ & $\begin{array}{l}\text { Xylem } \\
\text { tissue } \\
\text { width } \\
\end{array}$ \\
\hline A1 & $0.30 \pm 0.12$ & $0.12 \pm 0.06$ & $1.50 \pm 0.70$ & Elliptic & $0.12 \pm 0.04$ & $0.05 \pm 0.007$ & $0.40 \pm 0.09$ & $0.22 \pm 0.02$ & Polygonal & $0.16 \pm 0.00$ & $0.13 \pm 0.02$ & $0.12 \pm 0.007$ & $0.10 \pm 0.02$ \\
\hline $\mathrm{A} 2$ & $0.25 \pm 0.02$ & $0.15 \pm 0.007$ & $3.50 \pm 0.70$ & Elliptic & $0.18 \pm 0.03$ & $0.12 \pm 0.01$ & $0.43 \pm 0.07$ & $0.21 \pm 0.02$ & Circular & $0.18 \pm 0.01$ & $0.16 \pm 0.01$ & $0.11 \pm 0.04$ & $0.12 \pm 0.03$ \\
\hline A3 & $0.23 \pm 0.02$ & $0.17 \pm 0.02$ & $2.50 \pm 2.12$ & Elliptic & $0.22 \pm 0.00$ & $0.18 \pm 0.02$ & $0.39 \pm 0.00$ & $0.20 \pm 0.01$ & Circular & $0.28 \pm 0.12$ & $0.17 \pm 0.04$ & $0.11 \pm 0.04$ & $0.12 \pm 0.04$ \\
\hline $\mathrm{C} 1$ & $0.22 \pm 0.02$ & $0.10 \pm 0.01$ & $2.50 \pm 2.12$ & Elliptic & $0.17 \pm 0.007$ & $0.16 \pm 0.007$ & $0.37 \pm 0.01$ & $0.19 \pm 0.007$ & Circular & $0.17 \pm 0.00$ & $0.14 \pm 0.01$ & $0.13 \pm 0.02$ & $0.13 \pm 0.007$ \\
\hline $\mathrm{C} 2$ & $0.21 \pm 0.01$ & $0.10 \pm 0.00$ & $3.50 \pm 2.12$ & Elliptic & $0.17 \pm 0.007$ & $0.16 \pm 0.007$ & $0.33 \pm 0.04$ & $0.20 \pm 0.01$ & Circular & $0.17 \pm 0.007$ & $0.14 \pm 0.007$ & $0.13 \pm 0.03$ & $0.14 \pm 0.01$ \\
\hline C3 & $0.20 \pm 0.007$ & $0.11 \pm 0.00$ & $2.00 \pm 1.41$ & Elliptic & $0.18 \pm 0.01$ & $0.16 \pm 0.02$ & $0.32 \pm 0.03$ & $0.20 \pm 0.007$ & Circular & $0.17 \pm 0.007$ & $0.14 \pm 0.007$ & $0.14 \pm 0.04$ & $0.14 \pm 0.01$ \\
\hline CR1 & $0.23 \pm 0.05$ & $0.16 \pm 0.02$ & $5.50 \pm 0.70$ & Circular & $0.21 \pm 0.007$ & $0.13 \pm 0.00$ & $0.23 \pm 0.10$ & $0.18 \pm 0.03$ & Circular & $0.11 \pm 0.01$ & $0.08 \pm 0.007$ & $0.12 \pm 0.02$ & $0.09 \pm 0.007$ \\
\hline CR2 & $0.21 \pm 0.03$ & $0.15 \pm 0.01$ & $3.50 \pm 2.12$ & Circular & $0.13 \pm 0.00$ & $0.11 \pm 0.02$ & $0.31 \pm 0.007$ & $0.18 \pm 0.02$ & Circular & $0.18 \pm 0.04$ & $0.14 \pm 0.02$ & $0.12 \pm 0.02$ & $0.08 \pm 0.007$ \\
\hline D1 & $0.21 \pm 0.03$ & $0.12 \pm 0.01$ & $4.50 \pm 0.70$ & Elliptic & $0.21 \pm 0.01$ & $0.10 \pm 0.00$ & $0.34 \pm 0.07$ & $0.17 \pm 0.04$ & Polygonal & $0.11 \pm 0.01$ & $0.08 \pm 0.01$ & $0.12 \pm 0.007$ & $0.11 \pm 0.02$ \\
\hline P1 & $0.14 \pm 0.007$ & $0.11 \pm 0.03$ & $4.00 \pm 0.00$ & Circular & $0.17 \pm 0.00$ & $0.15 \pm 0.007$ & $0.38 \pm 0.04$ & $0.23 \pm 0.007$ & Polygonal & $0.15 \pm 0.06$ & $0.11 \pm 0.02$ & $0.13 \pm 0.03$ & $0.14 \pm 0.01$ \\
\hline P2 & $0.19 \pm 0.04$ & $0.13 \pm 0.04$ & $5.00 \pm 1.41$ & Circular & $0.15 \pm 0.02$ & $0.13 \pm 0.007$ & $0.33 \pm 0.04$ & $0.17 \pm 0.04$ & Circular & $0.11 \pm 0.03$ & $0.09 \pm 0.03$ & $0.10 \pm 0.03$ & $0.09 \pm 0.03$ \\
\hline P3 & $0.24 \pm 0.05$ & $0.12 \pm 0.007$ & $2.50 \pm 0.70$ & Circular & $0.18 \pm 0.007$ & $0.13 \pm 0.03$ & $0.43 \pm 0.07$ & $0.21 \pm 0.007$ & Polygonal & $0.15 \pm 0.04$ & $0.12 \pm 0.03$ & $0.12 \pm 0.007$ & $0.13 \pm 0.00$ \\
\hline V1 & $0.18 \pm 0.01$ & $0.12 \pm 0.007$ & $5.50 \pm 0.70$ & Elliptic & $0.14 \pm 0.02$ & $0.12 \pm 0.03$ & $0.37 \pm 0.03$ & $0.20 \pm 0.02$ & Polygonal & $0.22 \pm 0.00$ & $0.17 \pm 0.01$ & $0.11 \pm 0.02$ & $0.10 \pm 0.01$ \\
\hline V2 & $0.23 \pm 0.02$ & $0.15 \pm 0.02$ & $1.00 \pm 0.00$ & Elliptic & $0.16 \pm 0.007$ & $0.11 \pm 0.00$ & $0.39 \pm 0.00$ & $0.21 \pm 0.04$ & Polygonal & $0.15 \pm 0.02$ & $0.10 \pm 0.02$ & $0.12 \pm 0.007$ & $0.08 \pm 0.007$ \\
\hline
\end{tabular}


Table 3. ANOVA test among quantitative anatomical variables of the studied species and populations (Abbreviations ns: not significant, $* \leq 0.05, * * \leq 0.01$ )

\begin{tabular}{|c|c|c|c|c|c|}
\hline & & $\begin{array}{l}\text { Sum of } \\
\text { squares }\end{array}$ & df $\begin{array}{l}\text { Mean } \\
\text { square }\end{array}$ & $\mathbf{F}$ & Sig. \\
\hline \multirow[t]{3}{*}{ Epidermis cell length } & BG & 0.034 & 130.003 & \multirow{3}{*}{\multicolumn{2}{|c|}{$1.2370 .348^{\mathrm{ns}}$}} \\
\hline & WG & 0.030 & 140.002 & & \\
\hline & Total & 0.063 & 27 & & \\
\hline \multirow{3}{*}{ Epidermis cell width } & $\mathrm{BG}$ & 0.014 & 130.001 & \multirow{3}{*}{\multicolumn{2}{|c|}{$1.4860 .236^{\mathrm{ns}}$}} \\
\hline & WG & 0.010 & 140.001 & & \\
\hline & Total & 0.024 & 27 & & \\
\hline \multirow{3}{*}{$\begin{array}{l}\text { Epidermis cell } \\
\text { length/width ratio }\end{array}$} & $\mathrm{BG}$ & 53.429 & 134.110 & \multirow{3}{*}{\multicolumn{2}{|c|}{$2.3020 .067^{\mathrm{ns}}$}} \\
\hline & WG & 25.000 & 141.786 & & \\
\hline & Total & 78.429 & 27 & & \\
\hline \multirow[t]{3}{*}{ Epidermal layer no. } & $\mathrm{BG}$ & 3.141 & 130.242 & \multirow{3}{*}{\multicolumn{2}{|c|}{$3.1190 .022 *$}} \\
\hline & WG & 1.085 & 140.077 & & \\
\hline & Total & 4.225 & 27 & & \\
\hline \multirow{3}{*}{$\begin{array}{l}\text { Collenchyma cell } \\
\text { length }\end{array}$} & BG & 0.024 & 130.002 & \multirow{3}{*}{\multicolumn{2}{|c|}{$5.1480 .002 * *$}} \\
\hline & WG & 0.005 & 140.000 & & \\
\hline & Total & 0.029 & 27 & & \\
\hline \multirow{3}{*}{$\begin{array}{l}\text { Collenchyma cell } \\
\text { width }\end{array}$} & BG & 0.029 & 130.002 & \multirow{3}{*}{\multicolumn{2}{|c|}{$6.6150 .001 * *$}} \\
\hline & WG & 0.005 & 140.000 & & \\
\hline & Total & 0.034 & 27 & & \\
\hline \multirow{3}{*}{$\begin{array}{l}\text { Collenchyma cell } \\
\text { length/width ratio }\end{array}$} & BG & 3.194 & 130.246 & \multirow{3}{*}{\multicolumn{2}{|c|}{$6.1400 .001^{* *}$}} \\
\hline & WG & 0.560 & 140.040 & & \\
\hline & Total & 3.754 & 27 & & \\
\hline \multirow{3}{*}{$\begin{array}{l}\text { Parenchyma cell } \\
\text { length }\end{array}$} & $\mathrm{BG}$ & 0.071 & 130.005 & \multirow{3}{*}{\multicolumn{2}{|c|}{$1.6850 .172^{\mathrm{ns}}$}} \\
\hline & WG & 0.046 & 140.003 & & \\
\hline & Total & 0.117 & 27 & & \\
\hline \multirow{3}{*}{$\begin{array}{l}\text { Parenchyma cell } \\
\text { width }\end{array}$} & $\mathrm{BG}$ & 0.008 & 130.001 & \multirow{3}{*}{\multicolumn{2}{|c|}{$0.7340 .708^{\mathrm{ns}}$}} \\
\hline & WG & 0.012 & 140.001 & & \\
\hline & Total & 0.020 & 27 & & \\
\hline Parenchyma cell & $\mathrm{BG}$ & 1.240 & 130.095 & \multirow{3}{*}{\multicolumn{2}{|c|}{$1.0740 .446^{\mathrm{ns}}$}} \\
\hline \multirow{2}{*}{ length/width ratio } & WG & 1.244 & 140.089 & & \\
\hline & Total & 2.484 & 27 & & \\
\hline \multirow{3}{*}{ Phloem tissue length } & $\mathrm{BG}$ & 0.054 & 130.004 & \multirow{3}{*}{\multicolumn{2}{|c|}{$2.2570 .072^{\mathrm{ns}}$}} \\
\hline & WG & 0.026 & 140.002 & & \\
\hline & Total & 0.080 & 27 & & \\
\hline Phloem tissue width & $\mathrm{BG}$ & 0.024 & 130.002 & 3.10 & $10.022 *$ \\
\hline & WG & 0.008 & 140.001 & & \\
\hline & Total & 0.033 & 27 & & \\
\hline Phloem tissue & $\mathrm{BG}$ & 0.405 & 130.031 & $1.35^{\circ}$ & $570.289^{\mathrm{ns}}$ \\
\hline length/width ratio & WG & 0.321 & 140.023 & & \\
\hline & Total & 0.726 & 27 & & \\
\hline Xylem tissue length & BG & 0.002 & 130.000 & .192 & $0.997^{\mathrm{ns}}$ \\
\hline & WG & 0.013 & 140.001 & & \\
\hline & Total & 0.015 & 27 & & \\
\hline Xylem tissue width & $\mathrm{BG}$ & 0.011 & 130.001 & 1.866 & $560.130^{\mathrm{ns}}$ \\
\hline & WG & 0.007 & 140.000 & & \\
\hline & Total & 0.018 & 27 & & \\
\hline Xylem tissue & BG & 0.967 & 130.074 & 1.036 & $360.472^{\mathrm{ns}}$ \\
\hline length/width ratio & WG & 1.006 & 140.072 & & \\
\hline & Total & 1.973 & 27 & & \\
\hline
\end{tabular}

Note: BG: Between Groups, WG: Within Groups

According to CA-joined plot, each of the separated groups had specific trait (s), which was useful in identification of them (Figure 5). For example, epidermis layer number was a good characteristic for identification of populations CR1, P2, and V1 from the rest. Furthermore, population $\mathrm{C} 1$ had distinct characteristics such as collenchyma cell length/width ratio, epidermis cell width, and length/width ratio.

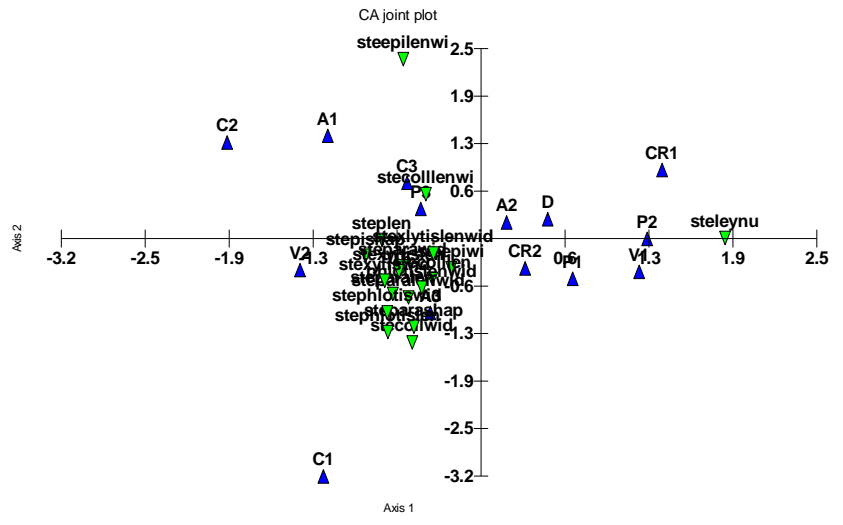

Figure 5. CA-joined plot of the anatomical variables with six species and populations (the blue symbols indicate species and their populations and the green symbols show anatomical characteristics).

\section{Discussion}

Different taxonomical patterns were proposed for the infrageneric classification of Marrubium species and various numbers of sections and sub-sections were definite for the genus (Bentham 1834; Boissier 1879; Briquet 1896). Moreover, taxonomic ranks of some taxa have changed in various Flora (Jamzad 2012). Therefore, in the current study, stem anatomical features were evaluated in six species of Marrubium in order to survey species relationship, delimitation and also comparison of these findings with previous molecular and morphological studies.

Previous researches on taxa of several dicotyledons and monocotyledons plant families (Metcalfe and Chalk 1950; Hammadi et al. 2002) have revealed the importance of anatomical characteristics on the palaeobotanical and taxonomical investigations. For example, Kantachot et al. (2007) suggested that anatomical data support morphological evidence for separating taxa at the generic level.

Moreover, we studied two to three populations from each species to examine effect of infraspecific variations on species relationship, except for $M$. duabense. Investigation of infraspecific variations has a great of importance in speciation and also species relationship at generic level (Talebi et al. 2014a, b). Previous investigations have revealed the high infraspecific morphological, phytochemical ( flavonoid data), and micromorphological ( calyx trichome) variations among $M$. cuneatum accessions (Kharazian and Hashemi 2017; Ahvazi et al. 2016) and also difference in leaf anatomical features in $M$. anisodon populations (Talebi et al. 2019).

The studied species and their populations were clustered separately in the UPGMA dendrogram, PCA and PCO plots of the stem anatomical characteristics. It revealed anatomical variations among the studied species and also their populations. Moreover, the ANOVA test showed significant difference for some quantitative features. We evaluated two qualitative anatomical characteristics. One of them, epidermal cell shape, varied 
among the species, while was stable among the populations of the same species. The other one, cortical parenchyma cell shape, not only differed among the species, but also varied infra-specifically. Pandey (2007) has stated that traits of epidermis, vascular bundles, rays, parenchyma, and phloem cells are some of the basic anatomical characters of well established taxonomic value.

It is more important to know that all of the studied populations of the same species did not group closely. In the UPGMA dendrogram, we had two separated clades; in one clade the populations of six and in the other clade the populations of five species existed. These conditions proved high infraspecific anatomical variations. For example, we evaluated three populations from $M$. anisodon, $M$. cuneatum, and $M$. parviflorum. The populations of two species, $M$. anisodon and $M$. parviflorum, were clustered in two clades far from each other. Although, populations of M. cuneatum were grouped in a clade, were placed separately far from each other. Similar results were reported from both M. crassidens populations, which were far from in a clade.

Furthermore, in the PCA plot, axis 1 acted a cut factor and divided the studied populations into two groups. Each group was composed of seven populations, while species compositions of these groups were not similar. In the left group we had all populations of $M$. cuneatum, but the right group including M. duabense and both populations of $M$. crassidens.

Ariyanejad (2018) studied infraspecific genetic variations of these populations and reported high infraspecific difference among populations of $M$. anisodon, M. cuneatum, and M. parviflorum. Especially individuals of $M$. parviflorum and $M$. anisodon populations were enveloped and the boundary of the studied populations was not clear. In similar, high infraspecific genetic variations were reported from $M$. cuneatum, M. anisodon, $M$. crassidens and M. vulgare by Salehi et al. (2018).

In some cases, our anatomical findings agreed with morphological classification of the species according to Jamzad (2012) and Rechinger (1982). For example, $M$. anisodon and M. vulgare are very similar morphologically and the main difference of them is related to length of calyx teeth (Rechinger 1982; Jamzad 2012). In a case, one population of these species placed closely in the UPGMA dendrogram, but other populations of these species did not group together. Similar results were reported by Salehi et al. (2018). They studied genetic diversity of several populations of five Marrubium species using ISSR data. They found that one population of $M$. vulgare was placed among different populations of $M$. anisodon, and was clustered with one of them as a pair. Besides, $M$. parviflorum and $M$. crassidens are morphologically very similar and these species are identified based on the calyx tooth shape. In two cases, populations of these species clustered closely and made the groups, while were placed far from each other. In Ariyanejad phylogeny work (2018), these species were clustered closely in the Maximum parsimony dendrogram of ITS data by bootstrapping value of $100 \%$.
According to Flora of Iran (Jamzad 2012), different synonyms have been definite for these species, and it reveals unstable position of these species. For example, at least five different varieties were reported for $M$. vulgare, even some authors like Trautv (1887) and Rechinger f. (1944) have believed that taxonomic rank of M. anisodon must be reduced as $M$. vulgare var. arcuata and $M$. vulgare var. oligodon, respectively. Meanwhile, Akgül et al. (2008) have suggested that phylogenetic analysis revealed close relations between $M$. anisodon and $M$. vulgare. Although, other populations of these species didn't cluster closely and these agreed with Salehi et al. (2018) findings of the mentioned species.

According to anatomical study, the delimitation of most species must be revised. In addition, some infraspecific ranks such as variety or subspecies must be defined for some species such as $M$. parviflorum and $M$. vulgare. Guerra and Nogueira (1990) suggested that the use of anatomical methods in taxonomic studies cannot be over emphasized. Although, no feature is absolutely immutable, some characteristics are more fixed than the others and it is on those that are less plastic that the systematic anatomist rely because they are not really affected by environmental factors. Comparative plant anatomy has been found to be reliable in taxonomy of many angiosperm taxa. Several botanists (Metcalfe and Chalk 1979; Naik and Nigrude 1981; Adedeji and Illoh 2004) have stated the taxonomic importance of anatomical characteristics, which along with other features are useful for identification and classification of plant taxa.

To conclude, we used the stem anatomical variables for taxonomical treatment of six Marrubium species and their populations in Iran. Most of the quantitative anatomical features did not vary significantly. However, the studied populations clustered separately in the UPGMA dendrogram and also PCA and PCO plots, and were divided into two distinct groups. Populations of the same species did not place closely and high infraspecific variations were recorded in the studied populations. Our findings agreed with previous infraspecific morphological, anatomical, molecular and phytochemical studied on these species. It seems that the some-infraspecific taxonomic ranks must be redefined for some species of the genus.

\section{REFERENCES}

Adedeji O, Illoh HC.2004. Comparative foliar anatomy of ten species in the genus Hibiscus Linn. in Nigeria. New Bot 31:147-180.

Ahvazi M, Jamzad Z, Balali G, Saeidi H. 2016. Trichome micromorphology in Marrubium L. (Lamiaceae) in Iran and the role of environmental factors on their variation. Iran J Bot 22 (1): 39-58.

Akgül G, Ketenoglu O, Pinar NM, Kurt L. 2008. Pollen and seed morphology of the genus Marrubium (Lamiaceae) in Turkey. Ann Bot Fenn 45: 1-10

Almeida VR, Costa AF, Mantovani A, Gonçalves-Esteves V, Arruda RCO, Forzza RC. 2009. Morphological phylogenetics of Quesnelia (Bromeliaceae, Bromelioideae). Syst Bot 34: 660-672.

Aoyama EM, Sajo MG. 2003. Estrutura foliar de Aechmea Ruiz \& Pav. subgênero Lamprococcus (Beer) Baker eespécies relacionadas. Rev Bras Bot 26: 461-473.

Ariyanejad F. 2018. Biosystematics and phylogeny study of some Marrubium species in Iran [Dissertation]. Arak University, Iran [Persian]. 
Bentham G.1834. Labiatarum Genera et Species. Ridgeway \& Sons, London.

Benzing DH. 2000. Vegetative structure. In: Benzing DH (Ed), Bromeliaceae: Profile of an Adaptive Radiation. Cambridge University Press, Cambridge.

Boissier PE.1879. Flora Orientalis. Regnum Academic Scientific, Basel.

Braga M. 1977. Anatomia foliar de Bromeliaceae da Campina. Acta Amaz 7: $1-74$.

Briquet J. 1896. Labiatae. In: Engler A, Pran HK (Eds.). Die Naturlichen Pflanzenfamilien. Engelmann, Leipzig.

Bukatsch F. 1972. Bemerkungen zur doppelfärbung astrablau-safranin. Mikrokosmos 61 (8):255-260.

Cullen J. 1982. Marrubium L. In: Davis PH (Ed.). Flora of Turkey and the Aegean Islands. Edinburgh University Press, Edinburgh.

Grassia A, Senatore F, Arnold NA, Bruno M, Piozzi F, Rigano D, Formisano C. 2006. Chemical composition and antimicrobial activity of the essential oils from aerial parts of two Marrubium sp. (Lamiaceae) growing wild in Lebanon. Pol J Chem 80: 623-8.

Guerra MD, Nogueira MTM. 1990. The cytotaxonomy of Emillia spp. (Asteraceae: Senecioneae) occurring in Brazil. Pl Syst Evol 170:229. 236.

Halvorson W. 2003. USGS weeds in the west project: status of introduced plants in southern Arizona Parks, Factsheet for Marrubium vulgare L., U.S.G.S.N.P. Service., Editor, U.S.

Hammadi KJ, Al-Mayah AA, Al-Rubaie IM. 2002. Comparative anatomical study of some genera of Polygonaceae in Iraq. J Basrah Res 28: 90-109.

Jamzad Z. 2012. Flora of Iran, No. 76: Lamiaceae. Ministry of Jihad-eAgriculture, Research Institute of Forests \& Rangelands Press, Iran.

Johansen DA. 1940. Plant Microtechnique. Mc Graw-Hill, New York.

Kantachot C, Chantaranothai P, Thammathaworn A. 2007.Contribution to the leaf anatomy and taxonomy of Thai Myrtaceae. Nat Hist J Chulalongkorn Univ 7 (1): 35-45.

Kharazian N, Hashemi M. 2017.Chemotaxonomy and morphological studies in five Marrubium L. species in Iran. Iran J Sci Technol 41: 17-31

Metcalfe CR, Chalk L.1950. Anatomy of the Dicotyledons, 2 Vols. Clarendon Press, Oxford, UK.

Metcalfe CR, Chalk L. 1979. Anatomy of the Dicotyledons: Systematic Anatomy of Leaf and Stem, with a Brief History of the Subject (2nd ed). Claredon Press, Oxford.
Moreno-Jimenez E, Gamarra R, Carpena- Ruiz R, Millán R, Penalosa J, Esteban E. 2006. Mercury bioaccumulation and phytotoxicity in two wild plant species of Almaden area. Chemosphere 63: 1969-1973.

Naik VN, Nigurde SM. 1981. Anatomy in relation to taxonomy of Chlorophytum (Liliaceae). Indian J Bot 4 (2):48-60.

Naghibi F, Mosaddegh M, Mohammadi -Motamed S, Ghorbani A. 2005. Labiatae family in folk medicine in Iran: from ethnobotany to pharmacology. Iranian J Pharmaceut Res 2: 63-79.

Pandey BP. 2007. A Text Book of Botany Angiosperms. Chand and Company Ltd., New Delhi.

Podani J. 2000. Introduction to the Exploration of Multivariate Data. Backhuys, Leiden.

Proença SL, Sajo MG. 2004. Estrutura foliar de species de Aechmea Ruiz \& Pav. (Bromeliaceae) do Estado de São Paulo. Acta Bot Bras 18: 319-331.

Radford AE, Dickison WC, Massey JR, Bell CR. 1974.Vascular Plants Systematics. Harper and Row, New York.

Rechinger K. 1982. Labiatae In: Flora Iranica, No. 150, Akademische Druch-u. Verlagsanstat, Austria.

Salehi N, Kharazian N, Shiran B. 2018. Genetic Diversity of Marrubium Species from Zagros Region (Iran), Using Inter Simple Sequence Repeat Molecular Marker. J Sci I R Iran 29(1):7-19.

Scarano FR, Duarte HM, Rôças G, Barreto SMB, Amado EF, Reinert F, Wendt T, Mantovani A, Lima HRP, Barros CFB. 2002. Acclimation or stress symptom? An integrated study of intraspecific variation in the clonal plant Aechmea bromeliifolia, a widespread CAM tankbromeliad. Bot J Linn Soc 140: 391-401.

Solereder H. 1908. Systematic Anatomy of the Dicotyledons. Clarendon Press, Oxford

Talebi SM, Atri M, Sheidai M, Sharifnia F, Noormohammadi Z. 2014a. Infraspecific variations in Linum album based on the determination of special stations approach method in Iran. Phytol Balcan 20 (1): 9-22.

Talebi SM, Salahi Esfahani G, Azizi N. 2014b. Inter and intrapopulation variations in Stachys inflata Benth. Based on phenotype plasticity (an ecological and phytogeographical review). Int Res J Biol Sci 3 (2): 920.

Talebi SM, Sheidai M, Ariyanejad F. 2019. Investigation of leaf anatomical structure variation among different populations of Marrubium anisodon C. Koch in Iran. J Cell Tissue 9 (4): 388-398.

Terrazas T, Arias S .2003. Comparative stem anatomy in the subfamily Cactoideae. Bot Rev 68 (4):444-473. 